\title{
THE BEGINNING OF
}

\section{MINING AND METALLURGICAL EDUCATION IN THE NEW WORLD}

The approaching 100th anniversary of the founding of our first school of mines at Columbia University reminds us that the New World's earliest achievements in mining and metallurgical education were those of the Spanish.

by F. R. Morral

n 1964, mining education in the United States will celebrate a 100th anniversary-that of the founding of our first school of mines at Columbia University. Prior to that, curricula leading to degrees in mining and metallurgical engineering were offered in 1853 by the Polytechnic College of Pennsylvania in Philadelphia. But the New World's earliest achievements in mining and metallurgical education were those of the Spanish in what is now Mexico.

American metallurgy probably goes back to Father José de Acosta, who in 1590 described the metallurgy of silver and mercury in the New World. ${ }^{1}$ The Spanish priest and metallurgist Don Alvaro Alonso Barba Toscano (1569-1662), in his book The Art of Metals, published in 1640, stated a need for a school of mining and metallurgical education in the New World. (The latest translation of this book was made by R. E. Douglas and E. P. Mathewson and published by J. Wiley \& Sons, New York, in 1923.)

In 1777 the first school of metals (Seminario Metalico) in the New World was created in Mexico City by a mining council. The next year a building was purchased for 31,000 pesos.

In 1783, the Royal Mining College (Real Seminario de Mineria) was chartered with a wellknown Spanish metallurgist, Don Fausto de Elhuyar*, as director. In 1790 , Don Fausto completed the preparation of a curriculum, and on January 1, 1792, the school opened. Subjects taught were mathematics, French, drawing, physics, mechanics, chemistry, and mineralogy. In addition, four theoretical courses in engineering were offered and two practical in residence courses at mines and metallurgical plants. It is interesting to note that the professors of mechanics, chemistry, metallurgy, mineralogy, and mining were paid 2000 pesos per year, while the mathematics professors received only 1500. Don Fausto's salary was 4000 pesos. $^{2}$

Don Fausto de Elhuyar and the men he asked to teach at the Royal Mining College had made reputations in mining and education in Spain or Mexico.

*Spelled "Lhuyard" in Basque works; also "Luyarte," “de Luyart," and "D'Elhuyart.

F. R. MORRAL, member of AIME, is senior research advisor of the Battelle Memorial Institute in Columbus, Ohio.
Don Fausto and his older brother, Juan Jose, are best known for isolating wolfram, but Don Fausto was also active in other mining and metallurgical research, such as melting platinum and investigating the production of crucible steel and the possibilities of making tinplate. ${ }^{3}$

The Elhuyar brothers ${ }^{2}$ had trained at Freiberg (established 1776) and had been professors at the Real Seminario Patriotico Vascongado in Vergara, Spain, which was founded in 1769. Don Fausto taught chemistry and mining there at the age of 28 . $\mathrm{He}$ was born in Logroño, Spain, on October 11, 1755, and received his education (in addition to Freiberg) in Paris, France, and Schemnitz, Hungary. When he was called to Mexico City in 1784, he was already known as the wise one. However, he was eventually lost both to research and teaching, his time being absorbed in administrative paper shuffling.

Two Spanish professors arrived in Mexico in 1794: Andres Manuel del Rio (1764-1849) ${ }^{2}$ taught mineralogy and Francisco Bataller, physics. These men held classes only three hours per week, since Don Fausto wanted them to prepare textbooks. This was the same Andres M. del Rio who discovered erythronium, now known as vanadium.

Beginning in 1798, graduates of the Royal Mining College received the title, Director and Mining Engineer. Von Humboldt (1769-1859), who visited the school about 1803, joined many other European scientists and engineers in praising the work being done there by the faculty and students.

Don Fausto returned to Spain in 1821 and became General Director of Mines in Madrid. He died there early in 1833 at the age of 77, leaving a wealth of reports on mining and metallurgical subjects.

An absorbing and complete account of early mining and metallurgy in Spanish America was compiled by Modesto Bargallo on the occasion of the fourth centenary of the discovery of the patio process in Pachuca by Bartolome de Medinia. This is La Mineria y la Metalurgia en la America Española Durante la Epoca Colonial, Mexico, 1955.

\section{References}

1 José de Acosta: Natural and Moral History of the Indies, 1590. 2 M. E. Weeks: Discovery of the Elements, 6th Ed., 1956.

3 Joaquin Almuno: Contribucion de la Real Sociedad Vascongada al Progreso de la Siderurgia Española a Fines del Siglo XVIII. Instituto del Hierro y del Acero, Madrid, Spain, 1951. 